\title{
'Remember the law of Moses': Malachi 3:22 in prophetic eschatology, with a missional postscript
}

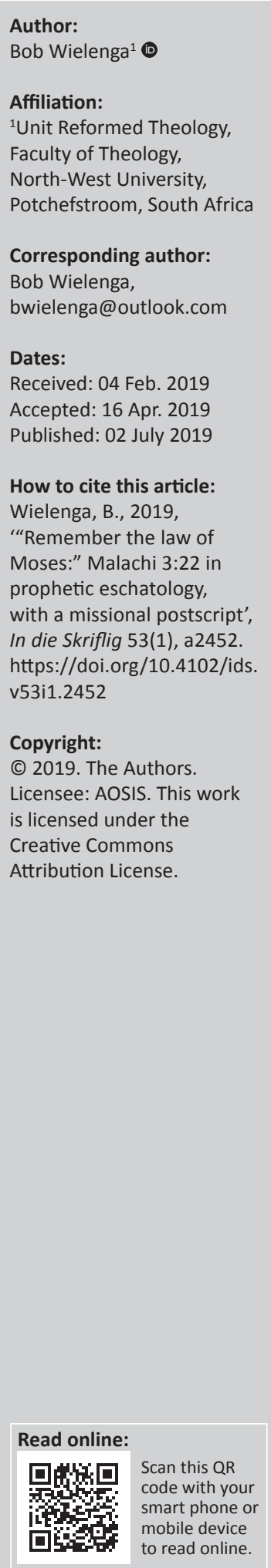

This study investigates the function of Malachi 3:22 in the context of prophetic eschatology as reflected in Malachi's message about the delay of the expected Day of the Lord, which focuses on the charge to 'remember the law of my servant Moses (...) I gave him at Horeb for all Israel'. This article examines the question how this charge serves the purpose of awaiting in the interim time the advent of the Day of the Lord. Firstly, a textual analysis is given of Malachi 3:22 in the context of the body of the book. Secondly, an eschatological application of the text is attempted with the help of selected texts from Deuteronomy 12:5, 11 (on worship) and 24:1-4 (on the treatment of women), addressing the problems in Malachi 1:6-2:9 and 2:10-16. Thirdly, the missional inferences of Malachi 3:22 for the present time are condensed in a postscript.

Keywords: Prophetic eschatology; Interim-ethics; Law of Moses: Dt 12: Name of God; Dt 24: Fair treatment of women.

\section{Introduction}

This article concurs with many scholars (Assis 2011:207-209; Chapman 2003:139-145; Snyman 2012; 2015:16-17, 182-185) that Malachi 3:22 is best understood as a deliberate editorial addition to the book it is attached to; it is plausibly, together with Malachi 3:23-24, the product of scribal prophecy (Chapman 2000:144-145). ${ }^{1}$ There are linguistic and thematic correspondence, but there are also differences with the body of the book (Snyman 2012:3). This justifies treating Malachi 3:22 (+23-24) as a separate but integral part of Malachi. This is not to deny that it also forms a canon-conscious conclusion to the Book of the Twelve Prophets or the Corpus Propheticum in its entirety and even to the canon of the OT as well (Chapman 2000:144). ${ }^{2}$ However, only the function of Malachi 3:22 is studied in the context of prophetic eschatology $y^{3}$ as reflected in the message of Malachi about the delay of the Day of the Lord (Wielenga 2018). It focuses upon the charge to 'remember the law of my servant Moses' and the question will be examined how this serves the purpose of awaiting the arrival of the prophet Elijah before the advent of the Day of the Lord (Ml 3:23-24).

Hence in the first section, Malachi 3:22 is textually analysed, answering the question of how to define the expressions used in the postexilic context of Malachi's time. The next section focuses on the question of how the implementation of Malachi 3:22 might be envisioned in the context of spiritual decline and moral decay as described by Malachi. An eschatological application of Malachi 3:22 is attempted with the help of selected texts from Deuteronomy to address specific concerns in the early postexilic community. In a postscript, some remarks are made about the missional relevance of Malachi 3:22 for the present ecclesiastical praxis.

This article is a sequel to three previous ones (Wielenga 2015; 2016; 2018) looking into the eschatology of the postexilic prophets from Haggai to Malachi. They offer information about the historical context and theological background of the early postexilic Persian era as reflected in the Book of the Twelve Prophets (Nogalski 2017; Sweeney 2000). ${ }^{4}$

\footnotetext{
1.See Stromberg (2014:195-218) for the occurrence of scribal prophecy in the postexilic era (3 Isa)

2.For the link between Malachi 3:22-24 and the tripartite canon structure of Pentateuch (Moses), former and Later Prophets (Elijah) and writings (Ps 1), see Snyman (2007; 2012).

3.For prophetic eschatology, see Gowan (2000), Collins (2003) and Grabbe (2003).

4.For the methodology used in this article, see Wielenga (2018:1; 1998:16-24; 1994:224-235).
} 


\section{Textual analysis of Malachi 3:22 The context}

Firstly, some introductory remarks are made about the literary context of Malachi 3:22.

The Masoretic arrangement of Malachi 3:22-24 is retained here. Not only on historical but also on theological grounds, it seems better to posit Moses before Elijah, the Law before the Prophets. ${ }^{5}$ As will be shown, it fits also the theological interpretation of Malachi 3:22 as proposed in this study. This final passage is taken as a literary unit with a unified message, even though two different literary genres could be discerned, defining verse 22 as an exhortation and verses 23-24 as divine speech (Snyman 2015:184).

No scholarly consensus has been reached about the question which source material has been used in the formulation of verse 22. It is common to point to Deuteronomic influences in view of its idiom: 'to remember the law of my servant Moses, the degrees and laws I gave him at Horeb for all Israel' (NIV). 6 But it is correctly pointed out that the idiom of verse 22 can also be found elsewhere in the OT. ${ }^{7}$ However, the focus of this study will be upon Deuteronomy, be it not exclusively so. In view of the covenantal character of Malachi's theology (Assis 2012:212-219; McKenzie \& Wallace 1983:549-563; O'Brien 1990:85-107; Weyde 2000:37-47), it is justifiable to read verse 22 at least also against the background of Deuteronomy with its emphasis upon the covenant as an actual, asymmetrical and mutual relationship between God and Israel (Wielenga 1998:49-53; 2016:2).

Secondly, the socio-economic situation of the early postexilic Persian period in Yehud must be considered in the light of the bearing it has on the people's response to the charge in verse $22 .{ }^{8}$ Politically, the returnees from exile were part of the Persian Empire as a semi-independent province; economically, they hardly survived as a rural subsistence economy, ravaged by droughts and locust plagues (Ml 3:10-11; Ha 1:5-6, 9-11; Jl 1-2), forced to pay taxes to the Empire and to materially support its occupation troops.

Thirdly, the apparent delay in the fulfilment of the eschatological promises made by the prophet Haggai (2:6-9, 20-23) in 520 вСе (Wielenga 2015; 2018) had left them spiritually depressed and led them to question God's justice (Ml 2:17; 3:13-14) and to neglect to observe God's covenantal 5.See for the discussion Assis (2011:208-209), and Snyman (2012; 2015:182-184).

6.In the body of the book, Deuteronomic influences can be traced; for example the impact of Deuteronomy 28-30 on the judgement pronouncement in Malachi 2:8, 12; 3:10-11. In Malachi's precursor in the Book of the Twelve, Joel, the Deuteronomic influence can also be noted (Wielenga 2018:2-3).

7.For inter alia, see 'Horeb' (also in Ex 3:1; 17:6; 33:6; 2 Chr 5:10), and 'all Israel' (in Dt 29:1, 10-11) but in Chronicles as well. Van der Woude (1982:157) suggests
Chronistic influences in Malachi 3:22; (see also Verhoef 1972:270 referring to $1 \mathrm{Chr}$ 22:13-17; $33: 8$ and Neh 10:29 for the expression 'degrees and laws'). This is also true for the other expressions in verse 22 .

8.The period described in Malachi is commonly located between 516-458 BCE, between the completion of the temple reconstruction and the arrival of Ezra. Dating Malachi 3:22-24 is not
(Snyman 2015:3-4). instructions (Ex 20-23; Dt 12-26). The failure of the teaching ministry of the priests ( $\mathrm{Ml} 2: 6-9)$ aggravated their apathy towards God dwelling among them in the temple.

This spiritual condition could theologically be described as covenant infidelity. Two breaches of the covenant are raised in the bitter dialogues between the prophet and the people: the vertical and the horizontal breach, both threatening the coherence of the postexilic covenant community (Wielenga 2016; 2018). God's presence among his people in the temple, the heart-beat of their existence as a faith community, is endangered by their apathetic worship and depressed spirituality. They also lack the required fidelity to the covenant's obligations for their daily life, compromising for instance their holiness by divorcing the wives of their youth to marry outside the faith women who remained faithful to their own gods (Ml 2:10-16). ${ }^{9}$ Both breaches of the covenant jeopardised the survival of the people facing God's judgement in the imminent and ultimate future (Wielenga 2018:3-4).

Fourthly, pastorally in the confrontation between prophet and people, the anger of God with especially the priests (Ml 1:6-2:9) was persuasively proclaimed; however, the prophet was aiming at the penitential return to God and his law. ${ }^{10}$ This can be inferred from the two images portraying the coming Day of the Lord from two different but coalescing perspectives. In its ultimate appearance that Day would be like a burning furnace (Ml 3:17-21), leaving nothing but ashes and no hope for any future at all. It creates a lasting separation among the population between those who were seeking the Lord and those who persisted in forsaking Him. But it could be averted, however, by remorseful return to God in conformity with the covenantal promises that there would be hope through judgement (Dt 27-30; Lv 26) - now compared with a refiner's fire (Ml 3:2-3), stressing the positive outcome of the expected Day (Wielenga 2018:4).

It is this community that is charged with remembering the law of Moses on its way into the future, awaiting the arrival of Elijah before the advent of the Day of the Lord.

\section{The text}

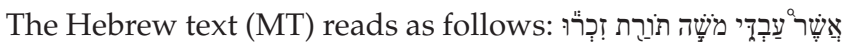

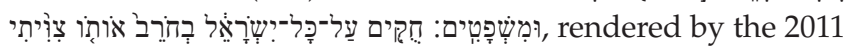
NIV-version used in this article as follows: 'Remember the law of my servant Moses, the decrees and laws I gave him at Horeb for all Israel' (Ml 4:4).

\section{To remember}

A preliminary remark is made about the nature of remembering in the nonliterate, oral culture of the ancient Near East. ${ }^{11}$

9.In Malachi 3:5, a series of horizontal covenant breaches are listed; see Isaiah 59 They are covered in Deuteronomy $12-26$ as well.

10. Notice the conditional character of the judgement prophecy ( $\mathrm{Ml} 2: 2$ - 'if') See Wielenga (2018:5), referring to Hays (2016), for the conditional character of eschatological prophecies, rooted in Malachi in the Deuteronomic covenant traditions.

11.Despite the probably high levels of literacy in the elitist circles of society, see Schaper (2005:333-340). 
The call to remember the law of Moses was heard in just such a culture. Remembering ancient traditions, transmitted throughout the ages orally or in written format, was the work of the Levitical scribes located in the temple (Van der Toorn 2007:51-108). As professional readers and writers they were trained in handling manuscripts and in memorising the ancient faith traditions among which the law of Moses took pride of place, passing them on to the people by reciting or reading them out aloud during the annual feasts in the temple (Dt 31:9-13; Neh 8:1). In nonliterate cultures, the oral mode of written texts is clearly discernible and strongly impacts the audience, sensitive as it was to hear the voice of the One who spoke through the texts in the first place (Neh 8:5-6). Before Ezra brought the 'book' of the law of Moses to Jerusalem (Ezr 6:18; 7:14), remembering the law of Moses would have been mainly dependent on oral traditions which were later confirmed by texts contained in the 'book' of the law of Moses Ezra had with him at his arrival in Jerusalem (Wielenga 2013:2-4). Through the office of the temple scribes the people were taught to remember what God had said ( $\mathrm{Ml} 2: 5-7$ ). To conclude, remembering the law of Moses had to be taught to have any impact at all on the people.

The charge to remember the law of Moses calls Deuteronomy 4-11; 27-32 strongly to mind, where Moses time and again, admonishes Israel to remember and not to forget ${ }^{12}$ the words spoken by God at Horeb through him as their mediator. To prevent that from happening, the importance of the teaching ministry of Moses (Dt 1:5; 4:1; 10:8-22; 11:31), of the parents at home (Dt 6:7, 20; 11:19), and of the priests in corporate worship (Dt 31:9-13) should be carefully acknowledged. Hence, remembering has a strong cognitive component without denying the more emotional one, as expressed in Deuteronomy 6:4-6, where Israel is charged to love God with their whole heart in response to God's love for her (Braulik 2012:553-555). This involves an active and careful observing of the divine instructions as originally taught by Moses, memorised by the scribes and also partly kept in written format by the temple staff next to the ark of the covenant (Dt 31:9, 26). ${ }^{13}$ The call not to forget the law of Moses but to remember it, is accompanied by strong warnings of divine judgement against persistently willful forgetting it (Dt 27:15-26; 28:15-68; 31:15-18; 32:15-26.

The teaching of the law of Moses as part of the ministries of the temple staff, covenanted to God to perform that sacred duty ( $\mathrm{Ml}$ 2:7), is also crucial in Malachi. Their failure to be faithful to this calling ( $\mathrm{Ml}$ 2:8) led to the people ignoring the careful observance of the law of Moses (Assis 2011:210), causing the covenant curses to be called down upon them (Ml 2:9; 3:2-3, 17-19). Hence remembering the law of Moses commences with a remorseful return to God and his decrees,

12.In Deuteronomy 4:9, to forget refers to a slow, half-conscious process defined by the expression 'slipping from your heart'; but in Deuteronomy 8:11, to forget refers to willful turning away from the law of Moses.

13.There is no need or no space to go into the diachronic debate on the provenance of Deuteronomy and its sources and their historical reliability. The synchronic approach of this article presumes the narrated time as presented in Deuteronomy and takes the book's authority in the postexilic era as decisive. See Arnold (2017a:139-160), Block (2001:385-408) and Vogt (2003:242-244; 2017:7-21). to start with the temple staff responsible for teaching the law of Moses (Ml 3:7). The prophet communicates in his addresses to the people the anger of God if they do not conform to the Deuteronomic traditions (Dt 30:9). This was 'key to his penitential call' (Boda 2015:153) to the priests first (Ml 2:3, 9), but subsequently to the people as well (Ml 3:2-3). The response to the prophetic call to repentance should be actualised through remembering the law of Moses. This implies that it contains the transforming power of a God who is really there and who does not remain silent.

\section{The law of Moses}

There is no scholarly consensus about the meaning of the expression 'the law of Moses' (Torath Mosheh). There is no need to sharply distinguish between the law of Moses as Pentateuch, as Deuteronomy or even more specifically as the Deuteronomic Code (Dt 12-26). There are good reasons to assume that the Pentateuch held an authoritative position in the postexilic era, and more specific in the post-Ezra period (Wielenga 2013:3-4). ${ }^{14}$ In Ezra 6:18 and 7:14, and in Nehemiah $8: 1,14$, the expression refers to the Pentateuch in oral as well as written form. It should not be surprising to find in Malachi references to the Pentateuchal traditions that the scribes must have been familiar with (Glazier-McDonald 1987:246-247). At the same time, it is beyond doubt that in Malachi, as has been argued, the Deuteronomic traditions in the Pentateuch are predominantly alluded to. In view of its idiom, this investigation in Malachi 3:22 will concentrate on the Deuteronomic Code (Dt 12-26), written down by Moses and to be kept by the Levites (Dt 10:8-9; 31:9, 26). It formed part of the documents that described the relationship between God and Israel as an asymmetrical but mutual covenant; they were to be annually read out loud during the corporate worship in the temple (Lohfink 1965:133).

This explains the character of the law of Moses: it is not so much a law code that is forced upon the people (Halberstam 2013:50-51), but a pronouncement of God's covenantal care for his people that is held out to them in love and that they should feel compelled to respond to in love (Braulik 2012:555-557). Despite the legal idiom, the religious purpose of the law of Moses was to help Israel to walk in God's ways in the Promised Land and to fulfil her God-given calling (Gn 12:3; Ex 19:4-6; Dt 4:5-8). Theologically formulated, the law was a gift of grace and a source of joy (Braulik 1994:27-54). ${ }^{15}$

The honorific title of 'my servant' for Moses, corresponds with the description of his high office in Deuteronomy: he is the sole mediator between God and Israel and God's preeminent spokesman (Dt 9:7-29; 18:14-18; 34:5, 10-12; Watts 1998:418-422). It stresses the authoritative, if not canonical, position of the law of Moses, including Deuteronomy 12-26,

14.For the present discussion on the literary relationship between the Pentateuch and EN, see Bautch (2016:531), who defends a synchronous relation between EN and a combined $P$ or non- $P$ Hexateuch.

15.The explanations of the meaning of the Hebrew word for law: Torah, are wellknown. It points to instructions from God as a father to Israel as his son (Ml 1:2-5 2:10; Ps 1; 119; Prov 1-11) 
certainly in the post-Ezra era, in which Malachi 3:22-24 must have been formulated and added to Malachi.

\section{The decrees and laws I gave him at Horeb for all Israel}

The law given at Horeb is described as the decrees and laws' (Dt 4:1; 5;1; 12:1). ${ }^{16}$ Van der Woude (1982:158) points out that this expression refers to the content of the law and not so much to the law as a written code. Specific areas of their future life in the Promised Land were covered by the law as spelled out in Deuteronomy 12-26 - in all spheres of life, private as well as public, God should be joyfully worshipped in compliance with the given law, to start with the worship in the temple (Dt 12; Arnold 2016; Block 2005:131-149). ${ }^{17}$ So, in Deuteronomy 16:18-18:22 public life (Levinson 2005:114-116; 2006:1884-1886; Lohfink 1993) and in Deuteronomy 21-24 family life are covered (Block 2010:463; Josberger 2008:36-220). Close attention is paid to socially vulnerable classes in society (Dt 14:28; 16:11, 14; 24:19-21; 26:12-13; Awabdy 2012; Lohfink 1990). Remembering the law of Moses indicated living life under the authority of God as revealed in his law, covering every inch of private and public life in the Promised Land, also in the postexilic era while awaiting the arrival of Elijah before the advent of the Day of the Lord (Ml 3:23-24).

\section{All Israel}

The expression 'all Israel' also requires attention (Verhoef 1972:269; Wielenga 2016:5-6). It appears in Malachi 1:1; 2:9 and 3:9 as well (Snyman 2015:24). In Deuteronomy, it is an often-repeated expression (Dt 5:1; 6:3; 17:20; 18:1 and so forth). At Horeb, Israel was perceived to be constituted as a unified nation covenanted to God, unique among the nations (Ex 19:5-6; Dt 4:6-9; 7:6; 26:19). In the postexilic context of Malachi, the representative name of 'all Israel' was granted to the remnant population of Yehud that would pass God's judgement as a refiner's fire on the coming Day of the Lord (Ml 3:2-3). It was this diminished Israel that was called to remember the law of Moses, by this fulfilling the nation's ancient calling since the days of the ancestors (Gn 12:3), reconfirmed at Horeb (Ex 19-24) and in the plains of Moab (Dt 26:16-27:10). ${ }^{18}$

\section{Eschatological application of Malachi}

In this section, the function of Malachi 3:22 in the eschatological discourse of the book is discussed without going into that discourse as such (Wielenga 2016; 2018). The points relevant to the argument developed here, are summarily sketched; then the discussion moves towards the relationship between the exhortation to remember the law of

16.The three terms (tora, huqqim, mishpatim) are also used in Malachi $2: 6-9 ; 3: 5$ 7 (Assis 2011:209).

17.The literature on Deuteronomy 12 is extensive; see for instance Arnold (2014), Paulo (2017) and Vogt (2003:167-211; 2017).

18.It is interesting to notice that the two prophetic personalities mentioned, Moses and Elijah, periodise Israel's history. The first witnessed the birth of the (12-tribe) nation, 'all Israel'; and the second announced its reconfiguration into a remnantstate, the 7000 who did not bow down before Baal (1 Ki 19:18).
Moses in Malachi 3:22 and the divine promise of the arrival of Elijah in Malachi 3:23, whose future ministry would

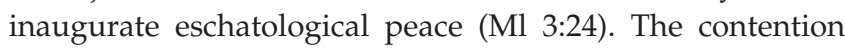
of this article is that, from a rhetorical perspective, the exhortation of Malachi 3:22 is pastorally motivated by the divine speech of Malachi 3:23-24. Hence, it is incorrect to regard this exhortation as abrupt in the flow of Malachi's dialogues; in the eschatological context of the book, it is rather logical (differently seen by Snyman 2012; 2015:183). Lastly, two examples are given of an eschatologically informed way of life in compliance with the law of Moses in the context of Malachi's book.

\section{Eschatological outline}

As earlier pointed out, the two images of divine judgement on the day of the Lord are used in a pastoral rhetoric to call the covenant-breaking people of God to repentance and to return to the God of their fathers (Ml 1:2-5). Irrevocable as the final judgement on the ultimate Day of the Lord may be, at the same time, it is still avertable. The assumption here is that the coming of the ultimate Day of the Lord can be delayed, caused by the prophetic ministry of the messenger of the Lord (Ml 3:1a), identified with the Elijah to come (Ml 3:23). ${ }^{19}$ This is predicated by the conditional character of eschatological prophecies. This causes the prolongation of the interim between the prophetic announcement and its fulfilment, which should be reason for joy, because of the possibility to escape the looming judgement by returning to the Lord in compliance with the law of Moses, even though it leads to the protraction of evil and suffering as well (Wielenga 2018:5).

The prophetic ministry mentioned in Malachi 3:23 entails the exhortation to remember the law of Moses. Calling the people back to a Torah-compliant life, formed part and parcel of the prophetic ministry that would find its preeminent spokesman in the prophet Elijah to come. The judgement on the Day of the Lord could only be expected to function as a refiner's fire and not as a burning furnace, if the people, beginning with the temple staff, would return to the standards of the law of Moses. Malachi 3:23-24 creates the right theological frame for Malachi 3:22. The call to Torah-compliance did not function in a growing legalistic discourse with exclusivist Jewish overtones, but in an eschatological one, pastorally composed in a covenantshaped frame of mind. In the present, defined by their redemptive past, they were called to await the advent of the Lord in the eschatological future (Ml 3:1) by remembering the law of Moses in the in-between time.

Because of space constraints, just two examples are given of how this active awaiting of the Day of the Lord, to arrive at an unspecified time in the future, might be envisioned. The situation in postexilic Yehud, as described in Malachi, requires immediate action on two fronts. As mentioned

19.In the NT, this prophetic ministry is taken up by John the Baptist (Mt 3:1-12) and later the apostles (Mt 28:16-20), causing the delay of the Parousia (Wielenga 2018:5-6) 
before, the worship of God in the temple by the spiritually depressed people was in disarray, while the unity of the covenant community was under threat by the growing practice of marrying outside the faith, increasing the number of ill-treated, divorced wives disproportionally and so threatening the coherence of the covenant people.

\section{To remember the law of Moses (1)}

In this first section, the failing temple ministries (Ml 1:6-2:9) are reviewed with the help of the Deuteronomic teaching about the worship of God at the place chosen by him where his Name has been established and he really dwells among them (Dt 12:5, 11).

\section{Despising the name}

The dispute with the temple staff takes centre stage in Malachi, counting for 18 of the 55 verses that the book comprises (Snyman 2015:53). The dispute revolves around the name of God being despised by the staff as evidenced in the two ministries mentioned here: their altar duties (Ml 1:6-14) and their duty to teach the people the law of Moses (Ml 2:1-9). They abused the name of the Lord Almighty (Yahweh Tsebaōth) by their offensive neglect of these duties they were covenanted to (Ml 2:4-5). ${ }^{20}$ Considering the frequent use of this double name in this section, it is important to understand its significance in Malachi's argument. ${ }^{21}$

The third commandment of the Decalogue (Ex 20:7; Dt 5:11) discloses how serious a transgression it was among Israel to injure the name of God, Yahweh (Houtman 1996:46-47; Van der Woude 1982:36-37). It referred to all practices that intentionally injured God's name, disparaging his reputation as Yahweh, the God who had revealed himself to his people from the time of the patriarchs onward (Gn 12:3), and with his name, Yahweh, first to Moses (Ex 3:14). The name Yahweh (Houtman 1986:102-108), with its covenantal connotations, recalled God's saving acts on behalf of Israel and defined who he wanted to be for them (a father: Ml 1:6; a husband, creator and redeemer: Is 54:5). God's name pointed to his presence among his people, not visibly through images, but rather aurally through his voice (Dt 5:1, 4, 22-26) and later, textualised through the law of Moses (Dt 4:1-40; 10:1-5; see Cook 2013:132; Sanders 2007:57-61, 69). Despising the name of God signified the disparagement of their redemptive origins, firstly by the temple staff covenanted to teach the law of Moses, but by the people as well. The Mosaic instructions pertaining the temple ministries suffered as consequence, and that not for the first time since the return from exile (Wielenga 2015).

But this covenantal name, connecting God with Israel (Dt 7:6), is associated here with the name Tsebaōth, referring most likely to the angelic hosts. This indicates that the God of

20.For 'the covenant with Levi' (Mi $2: 4-5$ ), see Snyman (2015:86) referring to Numbers 25:10-13; Deuteronomy 33:8-13 and Hosea 4:4-6.

21.This name, 'Yahweh Tsebaōth', appears nine times in this section; in Haggai 1-2, 12 times (Wielenga 2015:6 note 23); and in Zechariah 1-8, 23 times. It plays a centra role in the theology behind the eight visions (Rose 2012:186-187).
Israel is not a tribal God, even though he reigned, in preexilic times from above the Ark of the covenant in the sanctuary (2 Sm 6:8). From there he reigned sovereignly over the universe. The addition of Tsebaōth to the name Yahweh conveys the message that Israel's God is not like a tribal idol to be localised in one place only, and with its powers restricted to the territory of its worshippers..$^{22}$ As Yahweh Tsebaōth, he is great even beyond the borders of Israel (Ml 1:5), and his name will be great and feared among the nations (Ml 1:11, 14). It is not without good reason that in Malachi this double name appears just in this universal context. ${ }^{23}$ This second name also demonstrated God's power to protect his people in the politically oppressive situation of the Persian empire against its enemies within and without (Rose 2012:186-187). Being called by the name of this God was a covenantal privilege, distinguishing Israel from the nations, also beyond exile (Wright 2006:495-497), a privilege that could be revoked (Ml 2:7).

\section{Remembering Deuteronomy 12: Temple worship}

Awaiting the Day of the Lord at an unspecified date in future history, required the temple staff to remember the law of Moses and to start with his instructions concerning the temple worship they were responsible for (Dt 12:5, 11). ${ }^{24}$ Their culpable neglect of their responsibilities contributed negatively to the delay of the coming Day of the Lord and to its ultimate appearance as a burning furnace ( $\mathrm{Ml} \mathrm{3:19}$; see Wielenga 2018:5-6).

There is no need or room to go into the discussions around Deuteronomy 12 (Arnold 2014). The focus of the argument here is on how this instruction in temple worship should be remembered during the interim in which the people were called to await the coming of the Day of the Lord. Firstly, attention is paid to the presence of Yahweh Tsebaōth in the place chosen by Him. Secondly, the significance in Malachi's time, of the joy of worship in the presence of this God is observed. Thirdly, the reason why this section on worship opens the Deuteronomic Code (Dt 12-26) is examined. Lastly, the relevance of the antithetical nature of the worship of this God is considered in Malachi's context.

\section{Presentia dei ${ }^{25}$}

The actual presence of God in the one chosen place is stressed. Yahweh Tsebaōth established his name there, indicating that he himself dwelled at the place chosen by him in his grace (McConville 1984:30-31), in full authority over the land granted by him to his people. The reality of his presence is also expressed in the term 'in the presence of (or: 'before')

22.In the so-called pre-exilic Zion-ideology, this idea got hold of the people $(\mathrm{Jr} 7 ; 26)$. See Wielenga (1990:111-121) about this form of nationalistic Yahwism.

23.This could plead for an eschatological reading of these verses (despite Van der Woude's 1982:99-102 and Snyman's 2015:69-76 arguments). In Haggai 2:6-9, the apocalyptic temple vision is presented as an oracle of Yahweh Tsebaōth.

24.See Arnold (2016:161) for the significance of Deuteronomy 12-26 beginning with instructions for temple worship in line with the 1st and the 2 nd commandment (see also Lohfink 1965:129-141 re das Hauptgebot).

25. For the thesis defended by $M$. Weinfeld about secularisation and demythologisation as a result of the Deuteronomy 12 cult centralisation, see Arnold (2016:175) but especially Vogt (2003:42-46, 67-95). 
God' (Dt 12:7, 12; Vogt 2003:129). Cook (2013:141) compares the Horeb-experience of Israel (Dt 4:10-12; 5:23-27) with the one they would have at the one chosen place in the presence of Yahweh Tsebaōth. At Horeb, they encountered God's nearness not visibly but aurally; there were no images, but his voice was evidence of his presence. He spoke, and his words were mediated and interpreted by Moses, their official mediator, who was also instrumental in the presentation of Deuteronomy, in textualising the spoken words (Dt 31:9-13). Recapitulating and commemorating the presence of God as experienced at Horeb during worship at the one chosen place (Block 2005:133; Cook 2013:141) meant, apart from bringing sacrifices, listening to the teaching of the law of God as mediated through Moses - this must be continued in the land through the teaching ministries of the temple staff (Ml 2:5-7).

Remembering the law of Moses in the religious context of Malachi meant that the temple staff had to become aware again that it was this God they were supposed to serve in the temple: Yahweh Tsebaōth who was near to them in his sovereignty and grace through the teaching ministries they were neglecting. They had to become cognisant as well that neglecting the altar ministries would endanger the temple and its staff ( $\mathrm{Ml} \mathrm{2:3;} \mathrm{3:3).} \mathrm{Consequently,} \mathrm{it} \mathrm{would} \mathrm{also} \mathrm{inaugurate}$ the beginning of the end for all the people (Ml 3:19).

One should remember that Yahweh Tsebaōth, in the postexilic era, had again invested his name in the reconstructed temple (Hag 1:5-9) and that from there, in the eschatological future, peace would spread out over the world (Hag 2:9, 22). ${ }^{26}$ It should spiritually invigorate the people of Israel to invest, in response to these promises, in these ministries for the sake of the people's future, appreciating that Yahweh Tsebaōth did not depend on this place and its worshippers inside the borders of Israel (Ml 1:5, 11, 14).

\section{The joy of worship}

In the present climate of depressed spirituality and apathetic worship, the call to appear in the presence of Yahweh Tsebaoth with joy (Dt 12:7, 12, 18), should bring home to the temple staff the serious shortcomings of their ministries (Ml 1:7-8; Dt 15:21), quashing any hope of joy any pilgrim might still have cherished on his way to seek the face of the Lord (Dt 12:5; 28:47). The joy of worship (Braulik 1994:40-42; 2012:551-555) presumed a functioning covenantal relationship between Yahweh Tsebaōth and his people, that was based upon love, that was best described as fidelity with its emotional (Dt $6: 6 ; 30: 6$ ) as well as cognitive components (Dt 6:7-8; 31:12-13). The joy to be experienced in temple worship, in contrast with the ecstatic celebrations in the Canaanite cults (Arnold 2017a:1-18), should not be man-made but God-inspired, required, but not enforced. It was an answer to the salvation received from Egypt and exile (Dt 12:10; 30:3-10) and to the blessings experienced in their daily lives (Dt 12:7). The joy of worship should be shared as families together with Levites temple staff after the exile, and about the future of the temple. and socially vulnerable people dependent on their generosity (Awabdy 2012; Block 2005:135-136, 141-142). To bring back the joy in worship required reforming the worship practices to the Mosaic standards ( $\mathrm{Ml} \mathrm{3:3)}$ in order to re-energise the flagging spirits in the interim of waiting for the coming Day of the Lord.

\section{Sanctification of daily life}

The joy of worship was also supposed to find expression in the way daily life was lived and the state was organised in the land where Yahweh Tsebaōth was King. ${ }^{27}$ The literary structure of Deuteronomy possibly reflects this primacy of worship in Israel's private and public life. Deuteronomy has quite often been identified as a covenant document and paralleled with the suzerain-vassal treaties and their documents in the ancient Near East (Kline 1963). This parallel still has value (Vogt 2003:25-27). It would explain the positing of the Decalogue as a literary substructure of Deuteronomy (Braulik 2012:551; Lohfink 1965:133-135; Vogt 2003:25-27). It is not surprising then to find the first and the second commandment, covering the worship of God (Dt 12:1-16:17), at the head of Deuteronomy's central core (Dt 12-26), comprising Israel's 'draft constitution' (Levinson 2005:114). All spheres of life should be under the authority of Yahweh Tsebaōth, worshipped at the one chosen place, and whose holiness is thereby expanded to the entire land (Vogt 2003:199, 210, 245).

Remembering Deuteronomy 12 in the interim, would give direction to the people going into the future pending the advent of the Day of the Lord.

\section{'Not in their way'}

Lastly, the anti-Canaanite context of Deuteronomy 12 is decisive for understanding its message (Arnold 2016:165; Cook 2013:124; Vogt 2003:181). The obliteration of the idols' names, the destruction of their images and the demolition of their many shrines served only one purpose: only Yahweh Tsebaōth, who dwelled in the one chosen place, could be worshipped and served in his land - in his and not their way (Dt 12:2-4, 29-31), in line with the first and second commandment of the Decalogue. Positively formulated, they should seek his face only in his way where he wanted to be found.

In the postexilic period, the remnant population was called to worship God at the reconstructed temple in Jerusalem. This was contested by the Samaritans who claimed Mount Gerizim as the true place of worship of God. ${ }^{28}$ The returnees

27. Notice in Deuteronomy 17:14-20 the minimised political and judicial role of the king placed under the authority of the divine King from whom the law of Moses originates (Lohfink 1993:345; Vogt 2003:227-229), and this in absolute contrast with ancient Near Eastern praxis (Levinson 2005:89-96, 112, 115-116; 2006:1860-1863).

28.See Paulo $(2017: 35-39,136,141)$ about the difference between the Samaritan Pentateuch and the Masoretic Text of the Hebrew Bible regarding the identification of the one plac chos by God in Deuteronomy 12 . This agrees with the contestation of the one place chosen by God in Deuteronomy 12. This agrees with the contestation between Jews and Samaritans around the rebuilding of the Jerusalem temple a narrated in Ezra 4-6 (Wielenga 2013). The strife between returned Jews and their ( exile but had remained in the land) was religious in nature, even though political and economic motifs played a role as well; the danger of syncretism, however, was perceived by Malachi as the real threat to the people (see also MI 2:10-16). 
from exile were exposed to influences from outside their faith community as illustrated by the rise of interfaith marriages (mixed marriages) in the early Persian period (Ml 2:10-16; Ezr 9-10; Neh 13). The decline of the temple worship and the disappearance of its joy opened the people up for serving God not in his way, but in theirs.

Remembering the law of Moses in Deuteronomy 12 includes awareness of the strongly 'countercultural' worship that was asked for to give direction to the postexilic society in the in-between time that lay ahead.

\section{To remember the law of Moses (2)}

Because of space constraints, the second example of remembering the law of Moses in the in-between time is briefly examined: the treatment of women according to Deuteronomy 24:1-4 where, at first glance, the issue of divorce and remarriage looks to be raised (Josberger 2008:139-172). This issue of divorce in combination with mixed marriage is, in Malachi 2:10-16 (Snyman 2015:96-119), firmly placed on the reform agenda (see also Ezr 9-10; Neh 13). Reasons are not given for the emergence of this wellestablished practice of marrying outside the faith in the early postexilic era. In Malachi, it is obviously approached from a theological perspective (covenant) to urge the men in the community to change their way of life up to the Mosaic standards. Only one aspect of this practice, underlying the whole treatment of women during divorce procedures, will be studied here. Men should remember the law of Moses also in this specific situation (Dumbrell 1976:42-52). ${ }^{29}$

\section{The theological context of Malachi 2:10-16}

This section is united with the previous one through the theological concept of the covenant: firstly, the covenant with Levi (Ml 2:4) is broken by the priests, and now the covenant with the ancestors ( $\mathrm{Ml}$ 2:10) is broken by men marrying outside the faith (Glazier-McDonald 1987:83). There are more links between both sections: the most obvious one is the detestable treatment of the altar cult (Ml 1:7-8, 12-13; $2: 11,13)$. The mixed marriage issue is placed in a covenantal frame to fully reveal the spiritual crisis that had overtaken the people because of this basically syncretistic practice. Several inferences may be deduced from the text.

The covenant with the ancestors, most likely the one concluded at Horeb (Snyman 2015:104), had been unilaterally established by God as their Father who called them into being (Ml 2:10). As Yahweh Tsebaōth, He dwelled among them in the temple, deliberately localised in Jerusalem ${ }^{30}$ (Ml 2:11), where $\mathrm{He}$ expected to be worshipped in 'faithfulness' (Ml 2:10-11, 14-16). This term brings up the covenant as a bilateral relationship that has to be continued

29.Considering the poor socio-economic situation in Yehud, it could well be that marrying into the neighbouring well-established families of the landed inhabitants, some some of whom also claimed shared religious origins with them (see note 28), was regarded as a way out of poverty, advancing social security. Snyman (2015:114) suggests that costly polygamous marriages were nearly impossible in this period
because of poverty.

30.Maybe in opposition to the Samaritans' claim of Mount Gerizim as the chosen place (Dt 12), see note 28 . through the people's careful observance of its obligations, among which those concerning marrying outside the faith were not the least important ones (Dt 7:3-4). ${ }^{31}$ This covenantal perspective defined the people as a faith community with responsibilities towards God and one another (Ml 2:10). An important issue in a covenantal approach towards the relationship between God and his people was the upbringing of the children, representing the future of the covenant (Ml 2:15). The religious integrity of Israel as God's covenant people was at stake here (cf. Neh 13:23-27).

The well-known covenant sanctions (Dt 28-30; Lv 26) are here alluded to as well: the excommunication from the tents of Jacob of the men marrying outside the faith, and who were already experiencing God's displeasure with them (Ml 2:12-13). Possibly, one finds here an allusion to Genesis 31:33-34 (Snyman 2015:108): Jacob's wife, Rachel, is presented there as the prototype of 'the daughter of a foreign god' (Ml 2:11). This would explain the use of the unique expression 'the tents of Jacob'.

Hence, the practice of marrying outside the faith with divorce as facilitating agency, was disqualified here as a covenantbreaking practice, introducing syncretism and so desecrating the temple and defiling the name of God, decried as a detestable thing to do (Ml 2:11).

\section{'The garment of violence'}

As indicated earlier, the focus is now on the divorce practice, instigated by the husbands (as usual in the patricentric [Josberger 2008:12] cultures of the ancient Near East), and perceived in Malachi as a disruption of the communion with God (Ml 2:11-13), that inaugurated the dissolution of the community with one another (Ml 2:14-16). Both spouses equally participated in the covenant God had concluded with them as well, being members of the covenant people (Dt 5:2-3). The divorcing husband is addressed here ('you', second person singular), while his wife is conspicuously absent from the scene, as was usually the case in patricentric cultures (Snyman 2015:119).

Not without good reason (Gn 1:26-28; 2:20-23), the wife is called 'your partner' or companion, pointing to equality and not submissiveness in the spousal relationship (Snyman 2015:113). As wife of his youth (late teens), she deserved better from her marriage partner than to be dismissed for a foreign woman with access to more earthly goods and social standing. Faithlessness of the husband is blamed for the break-up of the marriage, towards God in the first place (Ml 2:11), but by consequence, towards the wife as well ( $\mathrm{Ml}$ 2:14).

Leaving a wife of long-standing for another one meant breaking up the marriage covenant, referring to the legal basis of a marriage contract with all what that involved..$^{32}$

31.See Wielenga (1998:45-120) for a biblical-theological treatment of the OT covenant concept.

32.There is an allusion here to the forensic basis of the covenant in the OT ( $G n$ 15:9-21; Ex 24:4-8; Dt 26:16-19): it was publicly concluded in a sacrificial ceremony with God being witness (Wielenga 1998:198-200). 
Publicly concluding a wedding ceremony was not just a civil arrangement, but it took place in the presence of witnesses of whom God was the chief one, solemnifying by his presence the ceremony as part of life in the land 'before God'. Hence, breaking the marriage covenant was foremost perceived as a controversy originating from the spiritual-religious sphere of life.

The reference to 'covering his garment with violence' (Ml 2:16), implicates the husband as the instigator of the process that did injustice to his wife of many years and left her, at least psychologically, hurt and him with a stained reputation (cf. Snyman 2015:118). In short, the terminology of this section (Ml 2:13-16) exposes the husband's ill-treatment of his abused wife who did not get a voice at all in the divorce proceedings.

\section{How not to treat women: Deuteronomy $24: 1-4^{33}$}

The casus raised in this section is complicated: a husband wanted to remarry his first wife after having divorced her some time ago. She was available again after her second marriage had ended in divorce or by the death of her husband. The cumbersome introduction to stating the casus (Dt 24:4) makes it look like an intentionally constructed case study (De Jong 1987:62-65) aimed at restricting the unbridled rights of men and at protecting the rights of vulnerable women. This interpretation concurs with the other cases of abused women discussed in this section of Deuteronomy (Dt 21:15-17; 22:13-21; 24:5, see Josberger 2008:36-132).

It is not about divorce or remarriage as such: the woman was divorced (maybe even twice) and did remarry (Dt 24:2-3). What is detestable in the eyes of the Lord and would defile his land, is the intention of the first husband to remarry the wife he had previously divorced. The detestable thing about it is that he first divorced her because of his displeasure with her after having found something indecent about her (Dt 24:1), and now, as if nothing had happened before, nothing untoward is there to prevent this remarriage to her. Hence, the vagueness about the indecency (Dt 24:1) could be intentional and used as a rhetorical device to put the husband on the spot as the one violating the rights of his wife who had to be protected against him. The need to obtain an official certificate of divorce could also be regarded as protecting the wife against an unrestrained, male dominated divorce practice. The expression 'after she has been defiled' (Dt 24:4) could be interpreted with Josberger (2008:162-165) as follows: her first divorce, forced upon her by her husband, made her 'defiled' in the eyes of the people. Her supposed indecency was, to begin with, brought up by her husband for ulterior motives.

The point the men in Malachi's time had to remember from Deuteronomy 24:1-4, was that their wives had rights which had to be protected. As husbands, they were called by God through the law of Moses to treat their wives as partners in

33.Just as in Malachi 2:13-16, also in Deuteronomy 24:1-4 the message is not about a timeless moral imperative prohibiting divorce in all circumstances, but about a timeless moral imperative prohibiting divorce in all circumstances,
timeless theological principle concerning the treatment of women. the marriage covenant, but in God's covenant with 'all Israel' as well. Awaiting the advent of the Lord to his temple, preceded by the prophet Elijah (Ml 3:1, 23), could only be done with assurance together as men and women, and in marriages that were pleasing in the eyes of Yahweh Tsebaōth who protects the vulnerable.

\section{Missional postscript}

A missional reading of Malachi 3:22 should pay attention to a New Testament application of the text and its message and account for the missional hermeneutics employed. ${ }^{34}$ The purpose of this section is, however, limited to a summing up of some of the missional inferences that could be deduced from the reading of the text as undertaken in this article. It postulates that in mission the missio dei and the missiones ecclesiae are distinguishable, but nevertheless coalesce in an asymmetrical, but reciprocal cooperation between God and his people, aiming at the completion of God's redemptive plan that will usher in a new world. There the sun of righteousness will rise with healing in its wings above those who revere God's name (Ml 3:20; Rv 21:1-7), but where there is no place for those who persistently refuse to await the advent of the Lord in compliance with the law of Moses (Ml 3:20-21; Rv 21:8; see Wielenga 2018:7-8).

The following missional inferences, at least, could be drawn from the text as analysed in this article.

Firstly, compliance with the law of Moses, giving direction to a God-pleasing life in the in-between time before the advent of the Day of the Lord, is sustained in the temple. The altar and teaching ministries during joyful worship services were intended to spiritually re-energise and redirect the people reconciled with God through the sacrificial office, for their public and private daily lives, enabling them to fulfil their God-given mandate in the land (Gn 12:3; Ex 19:4-6; Dt 4:6-8; Isa 49:6; Hag 2:6-9). This mandate could be described with the missiological term 'centripetal mission', intended to attract the nations to the temple in Jerusalem, where Yahweh Tsebaōth dwelled. ${ }^{35}$ One could apply this in this day and age, to the missiones ecclesiae receiving their inspiration, strength and direction from the liturgically structured Sunday worship services around the ministries of Word and Sacrament (Wielenga 1998:277-281). ${ }^{36}$ That worship has to be joyful to inspire to missional action, and does not need to be explicated in the light of Malachi's message.

Secondly, the anti-Canaanite character of the temple worship had to be translated in public and private life in compliance with the law of Moses. In modern parlance, one could speak

34.For a missional reading of Malachi focusing on the delay of the Day of the Lord, see Wielenga (2018:6-9) with attention paid to the missional hermeneutics, in line with Goheen (2016). See also Wielenga and König (1999:255-272) for a systematic theological treatment of missional hermeneutics from a covenantal perspective.

35.Centrifugal mission is anticipated in the OT, but firmly put on the agenda of the church in the NT (Mt 28:16-20); see Wielenga (2002:111-119).

36.That the worship service is rather dimensionally and mostly not intentionally orientated on mission, does not diminish its unrelinquishable unity with it (Wielenga 2013:7-8) 
here of a 'countercultural' way of life (Wielenga 2013:7). The example studied, the treatment of wives in divorce procedures, showed that a missional life should be relevant to the context in which one finds oneself: in postexilic Yehud, it was in the context of a dominant patricentric culture with scant consideration for female rights and needs as was normal in the ancient Near East. A missional reading of God's word is a contextualised, and not a timeless, reading (Jensen 1997:113-118) that could bring the church into conflict with the surrounding culture in which it participates nowadays. But it could also lead to internal turmoil within a church, that is not really open anymore to listening to God speaking through his Word in the present time. ${ }^{37}$

Thirdly, the gracious prolongation of time before the advent of the ultimate Day of the Lord create space for the people to return to God and his law, thereby averting the coming Day as a burning furnace. In the New Testament, this teaching is continued in the sayings about the delay of the Parousia (Mk 13:10; Mt 24:14) that serves the same purpose (Wielenga 2018:6). Hence, it is of importance to observe that in Matthew 28:20 'making the nations into disciples of Jesus' includes also, apart from baptising them in the triune Name, 'the teaching them to obey everything I have commanded you'. In the context of Matthew, one could think of Jesus' teaching in Matthew 5-7, where he explicitly states that he has not come to abolish the Law or the Prophets, but to fulfil them (Mt 5:17-18; 23:2-3). The charge to remember the law of Moses also forms part of the missionary mandate given by Jesus to his disciples and thus also to the church in the interim before his return. This charge should be taken as seriously by the missional church in the present time, as Israel was asked to do in the days of Malachi.

\section{Acknowledgements \\ Competing interests}

The author declares that he has no financial or personal relationship(s) which may have inappropriately influenced him in writing this article.

\section{References}

Arnold, B.T., 2014, 'Deuteronomy 12 and the law of the central sanctuary noch einal', Vetus Testamentum 64, 236-248. https://doi.org/10.1163/15685330-12341150

Arnold, B.T., 2016, 'Israelite worship as envisioned and prescribed in Deuteronomy 12 ', Zeitschrift für Altorientalische und Biblische Rechtsgeschichte 22, 161-176.

Arnold, B.T., 2017a, 'A singular Israel in a pluralistic world', in B.T. Arnold \& L.G. Stone (eds.), Distinctions with a difference: Myth, history, and Scripture in honour of J.N. Oswalt, pp. 1-18, First Fruits Press, Ashbury Theol. Seminary, Wilmore, KY.

Arnold, B.T., 2017b, 'The book of Deuteronomy: Pseudepigraphy, Pseudonymity, or something else?', in D.I. Block \& R.L. Schulz (eds.), Sepher Thorath Mosheh: Studies in the composition and interpretation of Deuteronomy, pp. 139-160, Hendrickson Publishers, Peabody, M.A.

Assis, E., 2011, 'Moses, Elijah and the messianic hope: A new reading of Malachi 3:22-24', Zeitschrift für alttestamentliche Wissenschaft 123, 207-220. https:// doi.org/10.1515/zaw.2011.013

Assis, E., 2012, 'Mutual recriminations: God and Israel in the book of Malachi', Scandanavian Journal of Old Testament Theology 26(3) 212-219. https://doi.org/ 10.1080/09018328.2012.730203

37.One could think of the excruciating debates around the position of women in conservative evangelical churches in the USA (or elsewhere), see Glahn (2017). Another example is the controversy around the Nashville Statement (2017) about Another example is the controversy around the Nashville Statement (2017) about
the position of the LBGT-community in church and society which fully expanded the position of the
Awabdy, M.A., 2012, 'He loves the immigrant: Deuteronomy's theological and social vision for the gēr', PhD thesis, Ashbury Theological Seminary, Wilmore, KY.

Bautch, R.J., 2016, 'Holy seed in Ezra-Nehemiah 9-10', in J.G. Gertz, B.M. Levinson, D. Rom-Shiloni (eds.), The formation of the Pentateuch: Bridging the academic cultures of Europe, Israel, and North America, pp. 525-542, Mohr Siebeck, Tübingen.

Block, D.I., 2001, 'Recovering the voice of Moses: The genesis of Deuteronomy', Journal of the Evangelical Society 44(3), 385-408.

Block, D.I., 2005, 'The joy of worship: Deuteronomy 12:1-14', Biblica Sacra 162, 131-149.

Block, D.I., 2010, “'You shall not covet your neighbor's wife": A study in Deuteronomic domestic ideology', Journal of the Evangelical Theological Society 53(3), 449-474.

Boda, M.J., 2015, 'Return to me': A biblical theology of repentance, InterVarsity, Downers Grove, IL.

Braulik, G., 1994, 'The joy of the feast: The conception of the cult in Deuteronomy: The oldest biblical festival theory', in G. Braulik (ed.), The theology of Deuteronomy: Collected essays, pp. 27-54, BIBAL Press, N. Richland Hills, TX.

Braulik, G., 2012, 'Die Liebe Gottes zwischen Gott und Israel: Zur theologische Mitte des Buches Deuteronomium', Internationale katholische Zeitschrift 41, 549-564.

Chapman, S.B., 2000, The law and the prophets: A study in Old Testament canon formation, Mohr Siebeck, Tübingen. (Forschungen zum Alten Testament 27).

Chapman, S.B., 2003, 'A canonical approach to Old Testament theology? Deuteronomy 34:1-12 and Malachi 3:22-24 as pragmatic conclusions', Horizons of Biblical Theology 25(1), 121-145. https://doi.org/10.1163/187122003X00105

Collins, J.J., 2003, 'Prophecy, apocalypse and eschatology: Reflections on the proposals of Lester Grabbe', in L.L. Grabbe \& R.D. Haak (eds.), Knowing the end from the beginning: The prophetic, the apocalyptic and their relationships, pp. 44-52, T Clark International, London. (Journal for the Study of Pseudepigrapha 46).
The

Cook, S.L., 2013, 'God's real absence and real presence in Deuteronomy and Deuteronomism', in N. McDonald \& I.J. de Hulster (eds.), Divine presence and absence in exile and postexilic Judaism, pp. 121-143, Mohr Siebeck, Tübingen. (Forschungen zur Alten Testaments 61).

De Jong, H., 1987, Deuteronomium 18-34: De evangelische wet, deel 2, Kok, Kampen.

Dumbrell, W.J., 1976, 'Malachi and the Ezra-Nehemiah reforms', The Reformed Theological Review 35, 42-52.

Glahn, S. (ed.), 2017, Vindicating the vixen: Revisiting sexualized, vilified, and marginalized women of the Bible, Kregel Academic, Grand Rapids, MI.

Glazier-McDonald, B., 1987, Malachi: The divine messenger, Scholars Press, Atlanta. (Society of biblical literature 98)

Goheen, M.W. (ed.), 2016, Reading the Bible missionally, Eerdmans, Grand Rapids, MI.

Gowan, D.E., 2000, Eschatology in the Old Testament, 2nd edn., Clark, Edinburgh.

Grabbe, L.L., 2003, 'Prophetic and apocalyptic: Time for new definitions - and new thinking', in L.L. Grabbe \& R.D. Haak (eds.), Knowing the end from the beginning: The prophetic, the apocalyptic and their relationships, pp. 107-133, Clark International, London. (Journal for the Study of Pseudepigrapha 46).

Halberstam, C., 2013, 'Torah, nomos: The discursive contours of Biblical law', Law, Culture and the Humanities 91(1), 50-58. https://doi.org/10.1177/1743872111 404174

Hays, C.M. (ed.), 2016, When the son of man didn't come: A constructive proposal on the delay of the Parousia, Fortress, Minneapolis, MN.

Houtman, C., 1996, Exodus, I; III, Kok, Kampen. (Commentaar op het Oude Testament).

Jensen, E., 1997, 'Women's issues in context', in C. van Engen, D.S. Gilliland \& P. Pierson (eds.), The good news of the Kingdom: Mission theology for the third millennium, Orbis Books, Maryknoll.

Josberger, R.L., 2008, Between rule and responsibility: The rule of the $A B$ as agent of righteousness in Deuteronomy's domestic ideology, ProQuest LLC, Ann Arbor, MI. (Southern Baptist Theological Seminary).

Kline, M.G., 1963, Treaty of the great king: The covenant structure of Deuteronomy, Wipf \& Stock, Eugene, OR.

Levinson, B.M., 2005, 'Deuteronomy's conception of the Law as an ideal type: A missing chapter in the history of constitutional law', Maarav 12(1-2), 83-119.

Levinson, B.M., 2006, 'The first constitution', Cardozo Law Review 27(4) 1853-1888.

Lohfink, N., 1965, 'Das Hauptgebot', in N. Lohfink (ed.), Das Siegeslied am Schilfmeer: Christliche Auseinandersetzungen mit dem Alten Testament, pp. 129-150, Joseph Knecht, Frankfurt am Main

Lohfink, N., 1990, 'Das deuteronomistische Gesetz in der Endgestalt - Entwurf einer Gesellschaft ohne marginale Gruppen', Biblische Notize 51, 25-40.

Lohfink, N., 1993, 'Distribution of the functions of power: The laws concerning public offices in Deuteronomy 16:18-18:22', in D.L. Christensen (ed.), A song of power and the power of song: Essays on the book of Deuteronomy, pp. 336-352, and the power of Song: Essays
Eisenbrauns, Winnona Lake, IN.

McConville, J.M., 1984, Law and theology in Deuteronomy, Sheffield University Press, Sheffield. (Journal of the Study of the Old Testament Supplement Series 33).

McKenzie, S.L. \& H.N. Wallace (eds.), 1983, 'Covenant themes in Malachi', Catholic Biblical Quarterly 45, 549-563.

Nogalski, J.D., 2017, 'Joel as literary anchor for the Book of the Twelve', in J.D. Nogalsk (ed.), The Book of the Twelve and beyond: Collected essays of J.D. Nogalski, pp. 137-156, SBL, Atlanta, GA.

O'Brien, J.M., 1990, Priest and Levite in Malachi, Scholars Press, Atlanta. (Society of Biblical literature Dissertation Series 121). 
Paulo, B., 2017, The centralization of the worship of Yahweh according to the Jewish and Samaritan Pentateuchs: A textual and theological study, PhD thesis, University of Stellenbosch, Stellenbosch.

Rose, H.W., 2012, 'Zechariah: Prophet of the king of Jerusalem and all the earth', in H.G.L. Peels \& S.D. Snyman (eds.), The lion has roared: Theological themes in the prophetic literature of the Old Testament, pp. 183-196, Pickwick Publications, Eugene, OR

Sanders, P., 2007, 'Geen beelden, maar teksten', in K. Spronk (red.), Deuteronomium, pp. 55-78, Skandalon, Amsterdam. (Amsterdamse Cahiers nr 23).

Schaper, J., 2005, 'Exilic and post-exilic prophecy and the orality/literacy problem' Vetus Testamentum 55(3), 324-342. https://doi.org/10.1163/1568533054359850

Snyman, S.D., 2007, 'Suffering in postexilic times - investigating Malachi 3:13-24 and Psalm 1', Old Testament Studies 20(3), 786-797.

Snyman, S.D., 2012, 'Malachi 4:4-6 (Heb. 3:22-24) as a point of convergence in the Old Testament or Hebrew Bible: A consideration of the intra- and intertextual relationships', HTS Teologiese Studies 68(1), a1195. https://doi.org/10.4102/hts. v68i1.1195

Snyman, S.D., 2015, Malachi, Peeters, Leuven-Paris-Bristol. (Historical Commentary on the Old Testament).

Stromberg, J., 2014, 'Deutero-Isaiah's restoration reconfigured', in L-S. Tiemeyer \& H.M. Barstad (eds.), Continuity and discontinuity: Chronological and thematic developments in Isaiah 40-66, pp. 195-218, Vandenhoeck \& Ruprecht, Köln. (Forschungen zur Religion und Literatur des Alten und Neuen Testaments 255).

Sweeney, M.A., 2000, 'Sequence and interpretation of the Twelve', in J.D. Nogalski \& M.A. Sweeney (eds.), Reading and hearing the Book of the Twelve, pp. 49-64, SBL, Atlanta, GA

Van der Toorn, K., 2007, Scribal culture and the making of the Hebrew Bible, Harvard University Press, Cambridge.

Van der Woude, A.S., 1982, Haggai, Maleachi, Callenbach, Nijkerk. (Prediking van het Oude Testament)

Verhoef, P.A., 1972, Maleachi, Kok, Kampen. (Commentaar op het Oude Testament).

Vogt, P.T., 2003, 'Religious concepts in the theology of Deuteronomy: A reappraisal of the Deuteronomic theology and the significance of Torah', PhD thesis, Gloucestershire University, Cheltenham.
Vogt, P.T., 2017, 'Deuteronomy: A history of its interpretation and its evangelical responses', in D.I. Block \& R.L. Schulze (eds.), Sepher Thorat Mosheh: Studies in the composition and interpretation of Deuteronomy, pp. 7-21, Hendrickson, the composition
Peabody, MA.

Watts, J.W., 1998, 'The legal characterization of Moses in the rhetoric of the Pentateuch', Journal of Biblical Literature 117(3), 415-426. https://doi.org/ $10.2307 / 3266439$

Weyde, K.W., 2000, Prophecy and teaching: Prophetic authority, form problems, and the use of traditions in the book of Malachi, Walter de Gruyter, Berlin-. https:// doi.org/10.1515/9783110811780

Wielenga, B., 1990, “'Volk van het land" als missiologisch model: Oude Testament en zending in Zuidafrikaanse kontekst', DTh thesis, University of South Africa, Pretoria.

Wielenga, B., 1994, 'Zendingshermeneutiek: een inleiding', in J. Bouma (ed.), Begeleidend schrijven: 25 Jaar Theologische Studiebegeleiding, pp. 224-235, Buijten \& Schipperheijn, Amsterdam.

Wielenga, B., 1998, Verbond en zending: Een verbondsmatige benadering van zending, Mondiss, Kampen.

Wielenga, B., 2002, 'Mission and the apocalyptic: A perspective from Matthew', International Review of Mission XCI 360, 111-119. https://doi.org/10.1111/ j.1758-6631.2002.tb00333.x

Wielenga, B., 2013, 'Renewal and reconstruction: Holy Writ in Ezra-Nehemiah: A missional reading', In die Skriflig/In Luce Verbi 47(1), a72, https://doi.org/10.4102/ ids.v47i1.72

Wielenga, B., 2015, 'Eschatological hope in Haggai: A homiletic reading', In die Skriflig/ In Luce Verbi 49(1), a1820, https://doi.org/10.4102/ids.v49i1.1820

Wielenga, B., 2016, 'Eschatology in Malachi: The emergence of a doctrine', In die Skriflig/In Luce Verbi 50(1), a2091, https://doi.org/10.4102/ids.v52i1.2091

Wielenga, B., 2018, 'The delay of the day of the Lord in Malachi: A missional reading', In die Skriflig/In Luce Verbi 52(1), a2362, https://doi.org/10.4102/ids.v52i1.2362

Wielenga, B. \& König, A., 1999, 'Zending: waarom? Verbond als antwoord' (E: Mission: Why? Covenant as answer), In die Skriflig/In Luce Verbi 33(2), 255-272. https:// doi.org/10.4102/ids.v33i2.627

Wright, C.H.J., 2006, The mission of God: Unlocking the Bible's grand narrative, IVP Academic, Downers Grove, IL. 